\title{
Religion, Terrorism and Weapons of Mass Destruction: Expediters or Hindrances for Global Peace
}

\section{| Ghada Awada}

Lebanese American University, Chouran, Beirut

ghadawada@gmail.com

\begin{abstract}
The purpose of the study was to examine the validity of the argument indicating that the religious nature of the terrorist groups accounts for the increase in the violence of terrorist acts today. The study also intended to explore the relationship between terrorism and religion and to address whether or not there has been interrelatedness between religion and terrorism. Another purpose was to explore the scope of Weapons of Mass Destruction (WMD) and to examine how religion was exploited to disseminate terrorism and eradicate global peace and how the possession of WMD could influence global peace. The study employed a metaanalysis of literature which pointed out the significance of religion and the controversy as to whether or not religion triggered terrorist violence. Incidents such as 9/11, the 2005 London underground attack, Paris attack, and 2019 attack in New Zealand were analyzed to serve the purposes of the study. The findings showed the main triggers and incentives behind the terrorist attacks waged in the name of religion. Overall, the findings of the study emphasized the influence of religion on terrorism, and vice versa. The study rendered conclusions that delved into infamous attacks and recognized terrorism as caused by religion or perceptions fogged by media and stereotypes.

KEYWORDS

Global Peace; media; religion; terrorism; WMD
\end{abstract}

\section{INTRODUCTION}

We are living in a world threated by terrorism and Weapons of Mass Destruction (WMD). Religious terrorism is a type of political violence motivated by the belief that another worldly power has authorized terrorist violence for the greater benefit of faith; terrorism in the name of religion has become the basic model for the extreme political violence in today's world. The relationship between religion and terrorism is one that goes back decades, from U.S. aircraft hijackings in the 1960s to the New Zealand mosque attack of 2019. Multiple factors may play a role in the terrorist attacks, such as desires for control, yet religion seems to be the most common scapegoat. This begs the question, 'is terrorism caused by religion?', or rather, is religion the most utilized and accepted excuse for terrorism? Following the attack by the Islamic-terrorist group Al-Qaeda, towards the World Trade Center of New York City, and the Pentagon of Washington D.C. on September 11, 2001, there has been an evident increase in stereotyping towards Islam and Muslims. Instances such as these make it clear that religion has a tarnished reputation, and in most cases it is Islam, a religion, like all, that promotes peace rather than chaos.

The bipolarity formed of the former Soviet Union and the United States came to an end with the collapse of the Former and the emergence of the unipolarity manifested by the victory of the western Bloc in 1991.Accordingly, “... scientists and civilians concerned about the destructive power of nuclear weapons... religious organizations and their leaders 
had always preached the gospel of peace, yet in the cold war period, some of them directly engaged in political activism"(Goedde, 2019, p.9).“The risk of war results from the anarchical order of power or the resulting security dilemma. Its prominent solution is "peace by strength" or "security by superiority" (Weede, 2019, p.3). Despite the clear international interest in nuclear disarmament, which is reflected in the agreement on a nuclear weapon ban in 2017, the ongoing modernization of nuclear inventories shows that real progress remains a distant goal. The nuclear states, United Sates, Russia, India, Iran and south Korea are interested in developing WMD.

There is hardly any term that has dominated reporting and political discussions in the past five decades like "weapons of mass destruction (WMD)".WMD are, as the name suggests, weapons that threaten indiscriminate destruction of large groups of people (Quester, 2017). These weapons are not necessarily used against conflicting armed forces but against entire populations; therefore, WMD are also used against people who are not involved in the war. Weapons of mass destruction as "indiscriminate" weapons are therefore outlawed by international law for a good reason. The Geneva Convention, which seeks to protect uninvolved civilians against the effects of war, is recognized and respected by almost all states in the world, and it specifically prohibits WMD: Atomic, biological and chemical weapons (Iannotti, Schraffl, Bellecci, Malizia, Cenciarelli, \& Di, 2016).

The use of WMD appeared in early $20^{\text {th }}$ century. In many conflicts, throughout the $20^{\text {th }}$ century and even earlier, and probably even earlier, diseases such as the plague or smallpox were used to weaken the enemy (Iannotti et al., 2016). Through industrialization and research, chemical weapons were added as well. During the First World War, about 120,000 tons of chemical warfare agents were used. As a result, about 100,000 soldiers died and 1.2 million soldiers were wounded. However, August 6, 1945 marked the beginning of a new era of weapons of mass destruction. On that day, the first atomic bomb detonated over the Japanese city of Hiroshima (Narang, Gartzke, \& Kroenig, 2015; Quester, 2017). Three days later, the second atomic bomb hit Nagasaki. According to estimates, more than 200,000 people died as a result of the two bombs. Many of the immediate survivors died from a deadly radiation dose (Quester, 2017). Even today, the descendants of the victims have a significantly higher number of cancers.

The use of these weapons cruelly showed the world the destructive power inherent in modern weapons systems. Therefore, it is believed that the possession of such weapons is a symbol of power explaining why a number of nations have in the past expressed their desire to develop or retain nuclear capacity. It is for the same reason why powerful states like U.S., Russia and UK among others are still retaining their nuclear capacities. With that said, this paper intended to demonstrate that WMD are used as a juxtaposition of power.

It is times like these in which this study proves to be vital, especially now, due to the plethora of attacks occurring more and more frequently. There must be a defense against the stereotyping of religious beliefs causing inhumane acts. Terrorism is not necessarily caused by religion, however, the two paths may intertwine at some point, and this is where is becomes essential to identify the divergence between the two. Nowadays, the media appears to have a say in who to blame for terrorist attacks. In a case of Australian media "the interpretation of the media discourse as defiantly anti-Muslim and the perception of the media as a powerful purveyor of public opinion has impacted on the construction of Australian Muslim identity" (Aly, 2007).

The study was set out to explore the nature/composition of Weapons of Mass Destruction (WMD) as the primary purpose. At the same time, the study investigated how WMD are used as a juxtaposition of power by nations. 
This study intended to explore whether religion has any influence on terrorism and do so by looking at instances in which acts of terror have taken place in the name of a religion. Investigating instances in which religion was wrongfully blamed for acts of terror, as well as discovering alternate reasons for menacing acts are essential components of the study. In addition, a priority of the study was to set forth and answer the following questions:

1. How is religion exploited to disseminate terrorism and eradicate global peace?

2. How does the possession of WMD influence global peace?

"Unfortunately, this reinforces the dilemma instead of overcoming it. That is why great power politics tends to be a tragedy. On the other hand, territorial delimitation or border issues play a major role. Because of rising economic development, the loss of strength gradient has lost some of its importance. Waging war against distant adversaries has become ever easier" (Weede, 2019, p.3). The world is still far from WMD decommissioning, and particularly, atomic disarmament. World nations are increasingly accustomed to pursuing state power over world peace. The last time this happened, the world went through two world wars that devastated masses all over the world owed to the nature of warfare and weaponry used- during that period, the world witnessed the devastating power of WMD. The world needs to be reminded of this devastating power

\section{LITERATURE REVIEW}

\section{Religion as a Trigger for terrorism}

Terrorism is caused by religion or rather the fact that terrorists view themselves as soldiers in the name of God fighting against God's enemies as a part of an ever-lasting battle of good against evil. However, from the author's point of view, the necessity of violence is built into the very structure of religious commitment. "We may say that religion causes violence if and when the perpetration of violence is a logical consequence of beliefs in unverifiable forces and/or beings" (Avalo, 2002, p.21). One fundamental problem in the analysis of the causes of terrorism is the lack of an accepted definition of terrorism. Badley (2002, p.92) stated, "The role of religion in international terrorism"; international terrorism is defined as "the repeated use of politically motivated violence with coercive intent, by non-state actors affecting more than one state" (Badley, 1998, p.92). Also, Avalo (2002) argues that religious studies scholars are guilty of defending the sacredness of scriptures that foster ferocity and disseminate the violent influence of these texts. Avalo added that religious violence is due to the scarcity of valued resources created by unverifiable religious claims. The scarce resources are the inscripturation of the words of a "supernatural entity; sacred space; group privilege; and salvation". Furthermore, the act of violence is often built into the base of the religious commitment such as the atonement act in Christianity, the sense of revenge in Judaism, and the martial triumphalism of Islam. Researchers have identified some major catalysts of terrorism. In developing countries, there is a relation between state sponsored political violence combined with existing unresolved intractable conflicts, and terrorism (Testas, 2004; Piazza, 2006; Çınar, 2009). For example, it is believed that the assassination of Ustaz Mohammed Yusuf in 2009, who was the founder of Boko Haram, provoked the members of Boko Haram to seek revenge through violence. The U.S. invasion of Iraq and the dethronement of Saddam Hussein in 2003 are said to have planted the seed for antiAmerican and anti-Western sentiments in the Arab world (Moghadam, 2006). The definition of terrorism has generated numerous debates within the academic arena, The arguments on defining terrorism from the level of impact it has on humans and their societies to the motivations for committing such atrocities, or from motivation to impact, showed how complicated, complex and nuanced the use of the term terrorism is within the academic arena (Lentini, 2008). Many early explanations of suicidal terrorism acts indicated that the nature 
or conditions in the "Muslim world" were the cause of the destructive phenomenon. Studies of Maddy-Weitzman (1997) and Ben-Dor (1996) have analyzed the impact of fundamentalism. However, other studies and analyses pointed to non-religious factors such as occupation, governmental repression, ethnic fractionalization, or inter-group competition. This development in the study of religion and political violence has led to diverging opinions among scholars of suicide terrorism, specifically concerning how religion influences suicide terrorism. This takes on a specific prominence when looking at the destructiveness of groups' suicide attacks; groups may adopt suicide terrorism for a variety of reasons; many of which have nothing to do with religion; Yet, religion-related beliefs and motivations can still affect how many deaths their attacks cause. It may be that fundamentalist groups focused on advancing their version of religion on a global stage since the bulk of destruction emanated from suicide attacks. As Esposito (1992) notes, "The challenge today is to appreciate the diversity of Islamic actors and movements, to ascertain the reasons behind confrontations and conflicts, and thus to react to specific presumptions and reactions" (p.168). Therefore, the role of religion in international terrorism has been exaggerated. While groups with religious affiliation engage in violence, factors other than religion appear to be the cause of this violence. Rather than serving as a catalyst for violence, religion is a means of polarizing populations, often taking the place of other ideologies that have failed.

\section{Terrorism on a political scale}

The position that religion is not the problem is taken by observers in opposition of the public discussion over religion after the 9/11 attack. In some cases, scholars see religion as a victim whereas many see it as an irrelevant ideology. "The presumed connection between suicide terrorism and Islamic fundamentalism is misleading and may be encouraging domestic and foreign policies likely to worsen America's situation and to harm many Muslims needlessly" (Pape, 2005). September 11 was a viscous and shocking incident. For more than 20 years, terrorist groups have been increasingly relying on suicide attacks to achieve major political objectives. From 1980 to 2003, terrorists across the globe waged 17 separate campaigns of suicide terrorism, including those by Hezbollah to drive the American, French, and Israeli forces out of Lebanon; Palestinian groups' acts could force Israel to abandon the West Bank and Gaza. According to the author "nearly all suicide terrorist attacks occur as a part of organized campaigns, states are uniquely vulnerable to suicide terrorists and third, suicide terrorist campaigns are directed towards a strategic objective; the sponsors of every campaign have been terrorist groups trying to establish or maintain political selfdetermination by compelling a democratic power to withdraw from the territories they claim" (Pape, 2005). Richardson, A US state department official, indicated that religion was being used throughout the Middle East to mask the problems that were essentially economic in nature. He assured that if jobs were to be had by unemployed Egyptians and Palestinians the problem of religious politics in the impoverished societies would quickly vanish. "Religion was the dependent variable, a rhetorical gloss over the real issues that were invariably economic or political" (Richardson, p. 138).

\section{Threats of weapons of mass destruction}

The term "weapons of mass destruction" (WMD) was coined in 1948 by the Commission for Conventional Weapons which was dissolved in 1952. Weapons of mass destruction are explosive nuclear weapons, weapons containing radioactive materials, as well as deadly biological and chemical weapons, and any weapons developed in the future whose destructive power is equal to that of the above-mentioned weapons (Iannotti et al., 2016). Nevertheless, only in 1969, the General Assembly addressed this issue and handed over the development of precise measures to prevent the redevelopment of WMD from the UN 
Conference on Disarmament (UNCD) (Thakur, 2017). Since then, various UN bodies have dealt with the issue, including the General Assembly, which regularly adopts relevant resolutions, as well as the UNCD (Quester, 2017). In particular, it is problematic that due to the definition of the term, it cannot be clear from the outset whether a new weapon system should be classified as a WMD. The ban on the development of WMD is therefore difficult to implement outside the known CBRN weapons. CBRN stands for Chemical, Biological, Radiological and Nuclear (Fountain, 2018). However, since the development of new weapons outside the CBRN classification, it is technologically quite unlikely that most of the new weapons are in the existing classification system. The ban does not have to deal in details with weapon systems outside the CNRN system but can focus on CBRN weapons (Narang et al., 2015; Quester, 2017; Thakur, 2017).

The further development of new generations of nuclear weapons (vertical proliferation) and "suitable "launchers, nonetheless, continued to establish the five nuclear-weapon states: US, Russia, France, China and UK (Quester, 2017). WMD strategies have been refined, resulting in a vast arsenal of strategic and tactical nuclear weapons for a variety of deployment scenarios. Although the number of WMD warheads around the world has continued to decline, the pace remains slow. At the same time, all nine nuclear powers are in the process of expanding their arsenals and technically upgrading them. Accordingly, the United States, Russia, Britain, France, China, India, Pakistan, Israel and North Korea had more than 14,465 nuclear warheads in 2016(Cordesman, Kendall, \& Colley, 2016). The peace researchers estimate that currently 3,750 nuclear warheads can be used operationally (Dunn, 2018). At the beginning of 2017, global stocks comprised 14,935 nuclear weapons and 460 fewer than in 2016. The decline was mainly due to the fact that Russia and the US further reduced their arsenals in 2010 following the signing of the "New START" bilateral disarmament agreement. However, both countries still own almost 92 percent of all nuclear weapons. The long-term strategy is also to modernize warhead inventories, missile and aircraft carrier systems and production facilities. Washington plans to invest about $\$ 400$ billion by 2026. The US Department of Defense declared in 2017 that the country reserves the right to develop new WMD. The other WMD powers, including India, Pakistan and China have much smaller arsenals. Nonetheless, they are also about to increase and develop newer WMD, according to the institute (Quester, 2017).

\section{Nature/Composition of Weapons of Mass Destruction (WMD)}

Currently, there are three major conventions for each of the three types of weapons of mass destruction, each dealing with one of the three types of WMD. WMD Conventions have emerged separately and differ greatly in their legal conception. Also, as far as their definition basis is concerned, they deviate strongly from the above-mentioned definition.

\section{Nuclear weapons (Atomic Weapons)}

Nuclear weapons are the most famous weapons of mass destruction, due to the historical experience of the Cold War. The fear of nuclear weapons and thus their "deterrent potential" is based on their objectively given destructiveness; The first bombings in Hiroshima and Nagasaki have become deeply engrained in people's minds (Narang et al., 2015; Quester, 2017). Currently, despite the commitment of nuclear weapon states to dismantle their nuclear arsenals, around 30,000 nuclear warheads are still in or out of reserve worldwide, most of them in the US. The possession of nuclear weapons of mass destruction is internationally regulated by the Nuclear Non-Proliferation Treaty (NPT) of 1968 (entry into force in 1970) (Müller, 2017). It has been recognized by 188 states. NPT controversially divided the world into states that can have nuclear weapons - the nuclear powers; USA, Russia, Britain, France 
and China and atomic "have-nots" (Berger, 2016). All the states of the world except Israel, Pakistan and India have shown compliance with the provisions of the NPT. These three countries have nuclear weapons and cannot enter the treaty until they have disarmed their nuclear weapons. The treaty obliges the "have-nots" not to acquire nuclear weapons or to strive for it. This part of the contract is general knowledge. The discussion about violations of countries that want to acquire the atomic bomb is becoming increasingly broader. States that are alleged to want to acquire nuclear weapons are considered rogue states and outlawed villains.

Today, the US is overwhelmingly involved in preemptive and preventive initiatives against the acquisition of nuclear weapons. Preemptive strikes are usually waged against opponents who pose the risk of attacking the US troops or allies using weapons of mass destruction. Preventive attacks target opponents who are about to acquire weapons of mass destruction. Opponents can be both states and non-state actors. Both approaches are extremely problematic under international law; a preventive approach is clearly contrary to international law. This applies even when strictly using conventional weapons. But if, as the US explicitly reserves, nuclear weapons are also used, this is almost always contrary to international law. What is more, the morality of preemptive and preventive initiatives but the U.S. is also a subject that has raised a lot of political debates especially given the fact that the US has in recent years not shown any intension or willingness to get rid of its nuclear arsenal (Lothringer, McGraw, Rautio, \& Thaxton,2016; Narang, Gartzke, \&Kroenig, 2015; Quester, 2017; Thakur, 2017).

In fact, the NPT also obliges the nuclear-weapon possessors in its Article VI to adhere to complete nuclear disarmament. In addition to the general commitment to nuclear disarmament, in a 13-point statement in 2000 , the nuclear powers have come to an "... unequivocal undertaking ... to accomplish the total elimination of their nuclear arsenal as leading to nuclear disarmament ..." (Müller, 2017). This part of the agreement by the atomic bomb possessors, however, is given almost no attention. But the non-compliant behavior of the nuclear powers deserves attention. The fact that the US and other nuclear states like Russia are less downsizing than upgrading should be a topic. In three new security policy and defense documents posted during the early 21st century, [Department of Defense January 2002, White House in September 2002, and White House in December 2002] the government outlined its plans to George W. Bush on how plans are underway to expand nuclear capacities. Even today, the prevailing official US policy is to create new and developed nuclear weapons that are more fit for war: "mini-nukes" and nuclear "EarthPenetrators", as well as nuclear weapons with reduced fallout effect. Also, the resumption of nuclear weapons tests is not excluded, but the preparation time for it is shortened. The nuclear test site in Nevada, which has not been used since 1993, might be reactivated. This might even be the reason why the U.S. continues to refrain from ratifying the international treaty signed by President Clinton for the Comprehensive Test Ban Treaty (CTBT) (Lothringer et al., 2016; Narang et al., 2015; Quester, 2017; Thakur, 2017).

\section{Biological weapons}

Biological weapons, synonymous with germ weapons, refer to weapons that uses the properties of disease-producing agents like viruses, bacteria, fungi, poisons etc. that can be harmful to living organisms (Dheilly, Poulin, \& Thomas, 2015).The Biological and Toxin Weapons Convention, adopted in 1972, came into force in 1975, with 151-member states today and 16 ratifying but not yet ratifying the convention (Haider, 2018). It contains a comprehensive and unequivocal ban on the entire military genre. Any development, production, storage or procurement of biological or toxin weapons is prohibited. Article 1 
states that: "Each State Party to this Convention undertakes never develops, produces, or otherwise obtains or retains any of the following: (1) Microbial or other biological agents, or toxins whatever their origin or method of production; "The Convention prohibits, without any restriction or exception, any hostile development or production of biological agents that can be used against humans, animals, plants or materials, it is not limited to war situations, and it does not provide for exceptions, such as for police use(Haider, 2018). However, the BTWC does not prohibit certain living organisms, but only their development for nonpeaceful purposes. This is, among other things, according to Sunshine Project, that these agents are subject to the dual-use problem, i.e. that they can be used both civilian and military. Even the most dangerous natural organisms can also be used for useful purposes. Practically all the knowledge and equipment needed for an offensive bioweapons program can also be used legally for civilian research in medicine and biology, or for research into defenses and protective agents (Dheilly et al., 2015)

Whether a particular experiment is offensive or defensive in nature is based solely on the intentions of the respective researchers. The dual-use problem makes it difficult to discover offensive biological weapon programs or to prevent a country from developing biological weapons. Since these bioweapons are usually self-replicating organisms, it is possible to obtain sufficient weapons-capable material in a very short time in order to make the regulation of certain aspects of this genre difficult.

Although the Biological Weapons Convention is very far-reaching and unambiguous in its prohibition of all biological weapons, it does not provide for any verification measures. After the emergence in the early 1990s (including a UN Special Commission, UNSCOM), Russia and Iraq had offensive B-gun programs, international negotiations to strengthen the Biological Weapons Convention began. In 1994, a Conference of the Parties to the BWC set up an ad hoc group mandated to draw up a legally binding protocol to strengthen the convention. The general approach to verification was relatively clear and broadly accepted by the negotiating partners in Geneva. It focused on existing biotechnology facilities and is based on measures that increase transparency between countries. The concept included the four pillars of declarations, visits, clarification procedures and investigations. In years of tug-of-war, the US has always been able to undermine and dilute the substance of the protocol. Above all, the US is opposed to compulsory visits to randomly selected laboratories. They claim that the danger of espionage, in particular industrial espionage, is too great. Among the forces in the US that support this position are the National Laboratories - who obviously do not want to tolerate visits to their B-arms research laboratories - and the Department of Commerce. In May 1999, the former US Secretary of Commerce William Daley refused visits on the grounds that they were not providing national security benefits. In addition, the US Pharmaceutical Industry Association (PhRMA) is a contributing factor to this given their very limited reporting requirements that oppose mandatory visits. Therefore, as a result of the US vehemence against assessment visits, there is still no verification mechanism that could be used to control or determine whether a state/country has a Biological weapons program or not (Dheilly, Poulin \& Thomas, 2015).

\section{Chemical weapons}

Chemical weapons are elements of mass destruction because they kill indiscriminately, rapidly, and tremendously large populations. They are relatively cheap to manufacture. The first chemical weapons were developed and used during the First World War. They were also used during the Second World War, the Vietnam War and the First Gulf War (1980 to 1988) (Price,2018).Chemical weapons consist of a chemical warfare agent and a carrier system to bring it to its destination. Chemical warfare agents have a suffocating, debilitating 
or toxic effect. Therefore, they have capabilities that can poison or damage the blood, as well as skin, lung, and the nervous system. The first chemical weapons simply consisted of the poisonous gases already known to the chemical industry, such as: chlorine or phosgene. Later, they synthesized new warfare agents specially developed for military warfare. The carriers may be mines, hand grenades, grenades, bombs, spray tanks or missile warheads. In the First World War, the warfare agents were spread in the form of gas; hence, the name is "poison gas". But gas evaporates very quickly, so the military later turned to using the warfare agent as an aerosol. An aerosol consists of a myriad of microscopic droplets that spread like a fog (Witkiewicz, Sliwka, \& Neffe, 2016).

The development, production, acquisition and use of chemical weapons are prohibited by the International Chemical Weapons Convention (CWC). This agreement, which joined a total of 161 states (including the US and Russia), entered into force in April 1997 (Among other things, Iraq and North Korea are non-members). States that are declared to be in possession of chemical weapons, such as the United States, Russia, South Korea or India, are obliged to destroy them. The size of the officially registered stocks is almost 70,000 tons, mainly in Russia and the USA. By the year 2000, only 5,400 tons had been destroyed in accordance with the regulations. The destruction process is making slow progress. This is because, given the tight budgets, Russia is willing to invest in expensive destruction only with foreign aid;therefore, the US sees no reason to hurry. Washington has also consistently withheld its payments to the Organization for review and implementation of the Convention, and has often shown little cooperative approach to verification visits in the United States (Witkiewicz et al., 2016).

\section{WMD as a juxtaposition of power by states}

The arms race between the U.S. and Russia was motivated by the need to gain world dominance or power. The threat of this race lead to the creation of the Nuclear NonProliferation Treaty of 1970 (Müller, 2017; Fountain,2018; Thakur, 2017).In the treaty, States Parties undertake "to conduct negotiations in good faith on effective measures to end the nuclear arms race in the near future and on nuclear disarmament and on a treaty for general and complete disarmament under strict and effective international control"(Müller, 2017). The stilted language shows how divided nuclear and non-nuclear weapons states were about the urgency of nuclear disarmament half a century ago. Nevertheless, the treaty put in place the principle of hope that one day the dead end of nuclear power in which the states of the world had ignited could be ended safely and irreversibly. For decades, peace movement, as well as military, southern and northern decision-makers, and most recently Barack Obama, who spoke in a sensational speech in Prague in 2009 about a nuclear-weapon-free world, subscribed to this hope. Be that as it may, this hope is about to say goodbye to the 21 st century (The White House, 2009). The proclaimed preventive strategy of the US, which was implemented in the 2003 Iraqi war confirms this logic (Cordesman et al., 2016). "But capitalist economic development and globalization can also contribute to pacification. There is something like a capitalist peace which depends on free trade, the avoidance of state-owned enterprises, and the avoidance of protectionism. Moreover, capitalism promotes prosperity and democracy which pacifies relations between democracies" (Weede, 2019, p.3).

\section{METHODOLOGY}

The study employed a qualitative descriptive research method in which a meta-analysis of existing literature was conducted. Studies discussing the relationship among religion, terrorism and WMM were analyzed. In addition, a survey consisting of 6 items was 
administered to solicit perceptions and opinions. The researcher was able to analyze the data provided to support the research results expected. The researcher utilized an inductive approach in addition to the descriptive and qualitative one, as the researcher analyzed the results. Therefore, a bottom-up approach was appropriately assigned in order to ensure the best results for the study, as the issue has been made clear, and the outcome is dependent on the data to support the topic.

\section{Research Design}

Qualitative study design intends to capture a hitherto unknown themes and patterns surrounding a given topic of study (Creswell \& Creswell, 2017). For research processes to be successful and valid, the researcher followed a special research design that fits the context of the inquiry at hand. So, the research design was the manner in which the research investigation was designed in order to answer the investigation questions, the topic of study, and the inquiry effectively. Depending on the selection of the problem of the planned research project, various methods and techniques of empirical social research were considered. The present study employed hypotheses derived using analysis methods such as significance tests, regression analysis, etc. As such, the researcher carefully approached the object of the study and left room for the discovery of new facts through the openness of the method. The current study set out to explore the particulars of religion and weapons of Mass Destruction (WMD) as the topic of interest to discover the themes and patterns that surround the subject. Because of the explorative nature of the topic, the most appropriate research design basis was the qualitative study design.

\section{Participants}

A survey was administered and 60 senior students pursing political science studies at an American university were randomly chosen to fill the survey out. The age of the students ranged from 20 to 26 years old.

\section{Data Sources}

Pursuing primary data in the context of the topic at hand is very complex. Thus, the study will depend on the secondary data sources from experts who have written about the issue in the wider literature. The search of secondary data was conducted through the internet systematically targeting literature that directly or indirectly addressed the topic of interest, i.e. Weapons of Mass Destruction (WMD).

\section{Data Analysis}

Secondary data were collected through thematic analysis. Using thematic analysis data is investigated with the aim of formulating relatively broad themes that summarize the content of the data. The first stem in this process involves data exploration. This takes place both during recording and by repeatedly reading or viewing the secondary data material. Only the researcher can perform this step since it is the basis for further development of the analysis. The second step is coding. These codes are not yet the themes that you will eventually get, it is more a technique to get to know the data better. Of course, this gives an initial idea or overview of the analysis. There are two possible approaches - Data-driven approach: coding is shaped by an analysis of the data. Theory-driven approach: the first coding is done on the basis of key elements from the theory used by the researcher. This study focuses of theory driven approach given the nature of the research questions. When this stage is done there is a possibility that the coded information sets appears to have different content. If this is the case, there is a need for a new label. If two codes contain similar coded information they may need to be fused together. Related codes are placed under a theme. Themes are therefore 
mainly the result of distributing the codes into more meaningful categories. Themes describe important patterns within the first codes. Opposite coding should not be described by different themes, they are just polar elements within the same theme. The fourth step involves the reviewing of the themes. Here, three possible consequences can arise: (1) There are few elements in the data that support the theme, so the theme will have to be removed or modified. (2) A specific theme must be split into two, be shared or subdivided as the data under a theme insinuate multiple themes or subdivisions (3) It is possible that certain data no longer fits within your theme and therefore have to be redistributed or formulated in a new theme. The fifth step is defining and labeling the themes. Although it sometimes seems easy to label a theme, it can prove very difficult to define it precisely. This takes time. The last step is writing the final report of the findings (Braun et al., 2019).

\section{RESULTS}

The data collected from the survey revealed that the majority of people between ages 18 to 21 believe that terrorism does not cause religion, and the group voiced their opinion on how to bring an end to the association between religion and terrorism, in addition to the following results.

Findings on Question 1: How is religion exploited to disseminate terrorism and eradicate global peace?

The data were analyzed from the survey utilized and the participants were asked if they thought religious-extremists are justified. $85.7 \%$ argued no, whereas the remaining $14.3 \%$ argued otherwise. For those who voted with the justification, it appears as though they hold the mentality that, "the inspection of religious extremism shows that theologies drive religious extremists and justify violence under the pretext of serving God" (Awada \&Habib, 2018, p.94). In multiple cases of terrorism, the acts are committed, as the terrorist would claim, 'in the name of God'. Whether these cases are justified or not, these may lead bystanders to view terrorism as an act committed by those who are devoted and faithful to a religion and carry out those acts in its name.

According to the survey, $71.4 \%$ of the participants voted with a simple 'no' whereas the remaining $28.6 \%$ viewed a possible reason for religion causing terrorism. The results of this question correlate to that of the first question, and the two appear to share similar justification. When a crime is committed, whether it be an act of terror, or a robbery, assumptions are made, either by average civilians or grouped media. These speculations usually revolve around preeminent stereotypes, such as blaming certain races for certain crimes, and in more extreme cases, attribute terror to certain religions. In contrast to this, however, Richardson (2006) argues,

"Many observers have pointed out that current religious conflicts are seldom about religion per se--they are about national territory, political leadership, and socioeconomic control all cast in a religious light. Within the wider public there is perhaps even less support for the notion that religion in general leads directly to violent acts" (p.134)

To obtain results for this research question, the group was presented with options to choose from of what religious group is most targeted, in the eyes of the media, for the attribution of terrorism. The options provided included, Islam, Christianity, Judaism, and a final option titles 'other' to add any religion excluded. An astounding 100\% voted that Islam, according to the media, are the most 'responsible' for acts of terror. Looking at examples, such as the infamous September 11, 2001 attack in New York City and Washington D.C. committed by Al-Qaeda, and others, the media, in the eyes of civilians appears to hold Islam as a stereotype for a majority of threatening acts. 
The participants were presented with the option to type their opinion, which proved to be the most suitable option, as it provided us with vital input from those who may feel affected by the issue at hand. A common answer was to stop blaming and relating everything to religion, as well, "Acknowledge that religion promotes peace rather than war and terror". Interestingly, there was a response relating to the previous question concerning media, stating, "The media should stop exaggerating the terror attacks when it is done by religious extremists while neglecting the terror attacks that are done by individuals. If the media stopped thinking about making profits and start thinking of spreading understanding, only then we can end this toxic relationship between religion and terrorism". Another response focused on an alternative use of media in the situation, "We can use the media to portray that terrorism isn't associated with Islam”.

Findings on Questions 2: How does the possession of WMD influence global peace?

The arms race between the U.S. and Russia escalated after the atomic booming of Japan. The stilted language shows how divided nuclear and non-nuclear weapons states were about the urgency of nuclear disarmament half a century ago. Nevertheless, the treaty put in place the principle of hope that one day the dead end of nuclear power in which the states of the world had ignited could be ended safely and irreversibly. For decades, peace movement, as well as military, southern and northern decision-makers, and most recently Barack Obama, who spoke in a sensational speech in Prague in 2009 about a nuclear-weapon-free world, subscribed to this hope.

A quick glance at the news headlines of recent decades is enough to make this clear: Between Brexit and the refugee crisis, the British Parliament is deliberating on a successor to its nuclear-equipped submarine fleet "Trident" London's closest allies on the other side of the Atlantic couldn't stay put without a response: as a result, Washington is considering making a comprehensive modernization of the American nuclear triad (air, sea and groundbased systems) for around one trillion US dollars over the next few decades. At the same time, Chinese strategists are considering turning their nuclear arsenal into a "hair trigger alert" mode and dreaming of their own triad and so-called multiple warheads for their missile programs in order to catch up with their western competitors. Anyone familiar with Asian armament dynamics knows that an Indian response will not be long in coming. And that will also ensure further Pakistani rearmament. No one will tolerate the idea of being left behind in this region. They all want to be powerful and give their people a sense of security. Finally, in response to the west, the Soviet nostalgic Vladimir Putin reactivated the good old tradition of the nuclear threat of the Cold War and refers to comprehensive modernization programs and new acquisitions in the Russian nuclear arsenal, with which his opponents would soon be expected. The reasons why the nuclear powers in this century are giving their weapons of mass destruction a second spring are as different as their security situation and their status claims. Also, worth a mention, supporters of nuclear weapons in emerging economies believe that only nuclear deterrence can prevent military intervention by the West.

\section{CONCLUSION}

To conclude, in accordance with the results of the survey, as well as the research provided, the questions raised have been successfully answered by various means. The survey provided the researcher with viable evidence from those who perhaps feel affected as well the need to share their input. In doing so, it became evident that a vast majority believes that religion is not a direct cause of terrorism, but perhaps the cause lies within the desire for territory, such as the conflict of Israel in the Middle East. As previously stated, acts of terror could also be carried out with the notion of control, whether it be political, economic or others, in mind. 
The media has also been proven to have an impact in the relationship between religion and terrorism, as the media may fuel the audience to believe that religion, in most cases Islam specifically, plays a role. From this it is urged that hasty assumptions, specifically in the media are refrained from being made, especially in severe cases of terrorist attacks. An element of research had initially justified the actions of religious extremists and their claim to carry out attacks in the name of God, yet most of the results of the survey proved the counter. Overall, with the results and elements of evidence and research, it is concluded that religion is in fact, not a cause of terrorism. Weapons of mass destruction (WMD)not only include nuclear weapons, but also biological and chemical weapons considered to have the ability of widespread devastation in terms of claiming lives and social and economic damage. The use, production and storage of WMD is largely prohibited and thus outlawed by arms control treaties that have had inconsistent rates of success. Nuclear weapons are the most effective WMD, releasing tremendous destructive energies in the form of heat, pressure, and radiation that would require a few thousand to a hundred thousand tons of conventional explosives. The appeal of WMD to emerging economies like Pakistan, India, China has never been greater than it is currently because most of these states believe that nuclear deterrence can prevent military intervention by the West. The possession of WMD guarantees security from possible invasion. The established nuclear states like the U.S. and Russia believe that the possession of WMD reflects the status which gives a sense of power at the world stage. A cocktail of these themes creates an environment that makes it impossible to implement successful WMD control policies. The study questioned the cause of terrorism, ranging from economic, political, to religious cases. In addition, the study further uncovered how the media impacted the crises. Furthermore, the study considered the impact of violence, religious or not, and how it could be identified and put to an end.

But one thing that stands out among the non-compliant nuclear states is that: each one sees itself as a "restrained nuclear-weapon state," which is being forced by other nuclear powers to nuclear retrofitting. No one sees himself as a driving force, all see themselves as driven. Fundamentally, with such a status quo, it is hard to formulate or act upon any disarmament efforts or deterrence initiatives. This brings us back to the question of whether terrorism is caused by religion. Religion is not the initial problem, but the fact that religion is considered to be the medium through which these issues are expressed is considered as a problem. Religious extremism is considered to be a complex phenomenon, it manifests as a severe form of conflict. Religion might have a cause in terrorism as proven by extremist groups within those religions being misled by their own holy scriptures.

\section{REFERENCES}

Badey, T. J. (2002). The Role of Religion in International Terrorism. Sociological Focus, 35(1), 81-86.

Berger, A. I. (2016). Life and Times of the Atomic Bomb: Nuclear Weapons and the Transformation of Warfare. Routledge.

Ben-Dor, G. (1996). The uniqueness of Islamic fundamentalism. Terrorism and Political Violence, 8(2), 239-252.

Braun, V., Clarke, V., Hayfield, N., \& Terry, G. (2019). Thematic analysis. Handbook of Research Methods in Health Social Sciences, 843-860.

Creswell, J. W., \& Creswell, J. D. (2017). Research design: Qualitative, quantitative, and mixed methods approaches. Sage publications.

Cordesman, A. H., Kendall, J., \& Colley, S. (2016). China's Nuclear Forces and Weapons of Mass Destruction. Washington, DC: Center for Strategic and International Studies. 
Dheilly, N. M., Poulin, R., \& Thomas, F. (2015). Biological warfare: microorganisms as drivers of host-parasite interactions. Infection, Genetics and Evolution, 34, 251-259.

Dunn, D. J. (2018). The first fifty years of peace research: A survey and interpretation. Routledge.

Fountain, A. W. (2018). Chemical, Biological, Radiological, Nuclear, and Explosive Threats: An Introduction. Handbook of Security Science, 1-6.

Goedde, P. (2019). The Politics of Peace: A Global Cold War History. Oxford University Press.

Haider, N. (2018). Chemical and Biological Weapons Conventions: Orienting to Emerging Challenges Through a Cooperative Approach. In Enhancing CBRNE Safety \& Security: Proceedings of the SICC 2017 Conference (pp. 253-260). Springer, Cham.

Habib, C., \& Awada, G. (2018). Religion and religiosity: A wrongful discourse or not? European Journal of Political Science Studies, 0. Retrieved from https://oapub.org/soc/index.php/EJPSS/article/view/453

Henne, P. S. (2012) The Ancient Fire: Religion and Suicide Terrorism, Terrorism and Political Violence, 24:1, 38-60, DOI: 10.1080/09546553.2011.608817

Lothringer, D. W., McGraw, M. S., Rautio, M. D., \& Thaxton, L. H. (2016). Countering Weapons of Mass Destruction: A Preliminary Field Study in Improving Collaboration. Naval Postgraduate School Monterey United States.

Maddy-Weitzman, B., \& Inbar, E. (Eds.). (1997). Religious radicalism in the greater Middle East (No. 4). Psychology Press.

Müller, H. (2017). The nuclear non-proliferation treaty in jeopardy? Internal divisions and the impact of world politics. The International Spectator, 52(1), 12-27.

Narang, N., Gartzke, E., \& Kroenig, M. (2015). Introduction: Nuclear posture, nonproliferation policy, and the spread of nuclear weapons. In Nonproliferation Policy and Nuclear Posture (pp. 17-28). Routledge.

Iannotti, A., Schraffl, I., Bellecci, C., Malizia, A., Cenciarelli, O., \& Di, D. (2016). Weapons of mass destruction: a review of its use in history to perpetrate chemical offenses. Def. $S \& T$ Tech. Bull, 9(1), 39-52.

Richardson, L. (Ed.) (2006). The Roots of Terrorism. New York, NY: Routledge.

Sahoo, R. (2016). Weapons of mass destruction in West Asia and its massive influence in Iran: An analysis. Ars Artium: An International Peer Reviewed-cum-Refereed Research Journal of Humanities and Social Sciences, 159-166.

Thakur, R. (2017). The Nuclear Ban Treaty: Recasting a Normative Framework for Disarmament. The Washington Quarterly, 40(4), 71-95.

The White House. (2009). Remarks by President Barack Obama In Prague As Delivered. Retrieved from https://obamawhitehouse.archives.gov/the-press-office/remarks-presidentbarack-obama-prague-delivered

Price, R. M. (2018). The chemical weapons taboo. Cornell University Press.

Quester, G. H. (2017). Preemption, prevention and proliferation: the threat and use of weapons in history. Routledge.

Witkiewicz, Z., Sliwka, E., \& Neffe, S. (2016). Chromatographic analysis of chemical compounds related to the Chemical Weapons Convention. TrAC Trends in Analytical Chemistry, 85, 21-33. 